\title{
Neurological effects of elevated levels of angiotensin II in COVID-19 patients
}

\author{
Mohammad Rafi Khezri ${ }^{1}$ [ $\cdot$ Morteza Ghasemnejad-Berenji ${ }^{1}$
}

Received: 8 August 2021 / Accepted: 25 August 2021 / Published online: 27 August 2021

(c) Japan Human Cell Society 2021

Keywords Angiotensin II $\cdot$ COVID-19 $\cdot$ SARS-CoV-2

Dear editor,

Coronavirus disease 2019 (COVID-19), caused by the severe acute respiratory syndrome coronavirus 2 (SARSCoV-2), has caused a great deal of damage to the world. Regarding the complications of this virus, although the pulmonary complications have received more attention, it can be very constructive to pay attention to its effects on the brain. Studies have been done on the effects of the SARS$\mathrm{CoV}-2$ on the central nervous system and it has been shown that this virus causes complications, such as seizure and cerebral hemorrhage [1]. About the probable mechanisms of these complications, increased entry of inflammatory cytokines into the brain as a result of the SARS-CoV-2 induced cytokine storm has been discussed. In this regard, angiotensin II (Ang II) can be a key factor in examining the association between the SARS-CoV-2 and the brain complications caused by it. After binding of the virus to its receptor, angiotensin-converting enzyme (ACE2), endocytosis of this receptor occurs with the virus [2]. Decreased levels of ACE2 at the cells surface increase Ang II levels, as reported in patients with COVID-19 [3]. Normally, Ang II cannot cross the blood-brain barrier (BBB), but in conditions, such as hypertension, increased levels of Ang II contribute to the BBB disruption [4]. It has been demonstrated that Ang II increases the BBB permeability through activation of the angiotensin II type 1 receptor (AT1R) [4]. Increased BBB permeability by Ang II can be a reason for the virus to enter the brain [5]. In addition, this condition can explain SARS-CoV-2-induced cerebral hemorrhage in COVID-19 patients, as the association between early BBB breakdown

Mohammad Rafi Khezri

Drmnkh76@gmail.com

1 Department of Pharmacology and Toxicology, Faculty of Pharmacy, Urmia University of Medical Sciences, Sero Road, Urmia, Iran and hemorrhage has been reported in patients treated with thrombolytic drugs [6]. On the other hand, following the entry of the virus into the brain [5], it may cause endocytosis of ACE2 leading to an increase in the levels of cerebral Ang II, which by binding to its receptors on astrocytes can cause the expression of inflammatory cytokines [7]. On the other hand, elevated levels of Ang II may contribute to neuronal loss in different parts of the brain. It has been shown that Ang II causes dopaminergic neurons death and losartan, an AT1R antagonist, protects these neurons against apoptosis [8]. In addition, the association between Ang II and Alzheimer's disease is examined in different studies. For instance, it has been indicated that ACE2 is decreased in Alzheimer's disease leading to increase tau pathology [9]. In addition, Ang II has been shown to increase brain $\mathrm{A} \beta$ through modulation of amyloid precursor protein production and $\alpha-, \beta$, and $\gamma$-secretase activities in an animal model of Alzheimer's disease [10]. Overall, based on the available evidence, the effect of the SARS-CoV-2 on elevated Ang II levels should be given more attention and further studies in this field can be constructive.

Author contributions Not applicable.

Funding Not applicable.

Availability of data and materials Not applicable.

\section{Declarations}

Conflict of interest There is no conflict of interest to declare.

Ethics approval and consent to participate Not applicable.

Consent for publication Not applicable. 


\section{References}

1. Serrano-Castro P, Estivill-Torrús G, Cabezudo-García P, ReyesBueno J, Petersen NC, Aguilar-Castillo M, et al. Impact of SARS-CoV-2 infection on neurodegenerative and neuropsychiatric diseases: a delayed pandemic? Neurología (English Edition). 2020;35(4):245-51.

2. Lukiw WJ, Pogue A, Hill JM. SARS-CoV-2 infectivity and neurological targets in the brain. Cell Mol Neurobiol. 2020. https:// doi.org/10.1007/s10571-020-00947-7.

3. Wu Z, Hu R, Zhang C, Ren W, Yu A, Zhou X. Elevation of plasma angiotensin II level is a potential pathogenesis for the critically ill COVID-19 patients. Crit Care. 2020;24:1-3.

4. Biancardi V, Stern J. Compromised blood-brain barrier permeability: novel mechanism by which circulating angiotensin II signals to sympathoexcitatory centres during hypertension. J Physiol. 2016;594(6):1591-600.

5. Song E, Zhang C, Israelow B, Lu-Culligan A, Prado AV, Skriabine $\mathrm{S}$, et al. Neuroinvasion of SARS-CoV-2 in human and mouse brain. J Exp Med. 2021. https://doi.org/10.1084/jem.20202135.

6. Kastrup A, Gröschel K, Ringer TM, Redecker C, Cordesmeyer R, Witte OW, et al. Early disruption of the blood-brain barrier after thrombolytic therapy predicts hemorrhage in patients with acute stroke. Stroke. 2008;39(8):2385-7.

7. Gallagher PE, Chappell MC, Ferrario CM, Tallant EA. Distinct roles for ANG II and ANG-(1-7) in the regulation of angiotensinconverting enzyme 2 in rat astrocytes. Am J Physiol-Cell Physiol. 2006;290(2):C420-6.

8. Grammatopoulos TN, Jones SM, Ahmadi FA, Hoover BR, Snell LD, Skoch J, et al. Angiotensin type 1 receptor antagonist losartan, reduces MPTP-induced degeneration of dopaminergic neurons in substantia nigra. Mol Neurodegener. 2007;2(1):1-17.

9. Kehoe PG, Wong S, Mulhim NA, Palmer LE, Miners JS. Angiotensin-converting enzyme 2 is reduced in Alzheimer's disease in association with increasing amyloid- $\beta$ and tau pathology. Alzheimer's Res Ther. 2016;8(1):1-10.

10. Zhu D, Shi J, Zhang Y, Wang B, Liu W, Chen Z, et al. Central angiotensin II stimulation promotes $\beta$ amyloid production in Sprague Dawley rats. PLoS ONE. 2011;6(1): e16037.

Publisher's Note Springer Nature remains neutral with regard to jurisdictional claims in published maps and institutional affiliations. 